\title{
Remanufacturing of Short Life-cycle Products
}

\author{
Shu San Gan \\ Department of Mechanical Engineering, Petra Christian University, Surabaya 60236, Indonesia \\ E-mail: gshusan@peter.petra.ac.id
}

\author{
I Nyoman Pujawan \\ Department of Industrial Engineering, Sepuluh Nopember Institute of Technology, Surabaya 60111, \\ Indonesia \\ E-mail: pujawan@ie.its.ac.id (Corresponding Author)
}

\author{
Suparno \\ Department of Industrial Engineering, Sepuluh Nopember Institute of Technology, Surabaya 60111, \\ Indonesia \\ E-mail: suparno@ie.its.ac.id
}

\begin{abstract}
Rapid development and innovation in science and technology have resulted in shorter product life-cycle, especially in technology-based commodities like mobile phones and computers. Mounting wastes from such products have received increasing attentions from government, society, as well as industries for sustainability concerns. Numerous studies on remanufacturing have been found on durable goods, but only a few focusing on short life-cycle products. Even though several studies implied that successful remanufacturing requires products to have long useful life and stable technology, there are other findings that support remanufacturing of short lifecycle products. It is our intention to investigate remanufacturing of short life-cycle product. A literature review is conducted to study the pros and cons, life-cycle implication, and remanufacturing aspects of short life-cycle products. Then we propose a framework that can be used to decide and plan the remanufacturing system. Furthermore, we conduct a survey to obtain descriptive analysis about the market potential for remanufactured short life-cycle products. The factors investigated are existence of demand, customer's willingness to pay (WTP), and existence of green segment. The survey results show that low-end customers are the potential market segment for short life-cycle remanufactured product, because they have the highest preference toward remanufacturing and $95 \%$ of them chose remanufactured product when the price is less than $40 \%$ of new product. It is also shown that green segment exists since $42 \%, 65 \%$, and $47 \%$ of customers from high-end, low-end, and student subgroup respectively consider buying remanufactured products over new ones driven by their concern for the environment.
\end{abstract}

Keywords: remanufacturing, short life cycle product, framework, survey, market potential

\section{INTRODUCTION}

In an increasingly competitive global market, innovation has become one of the keys for successful enterprises. Rapid innovation and development in science and technology coupled with rapid changes in consumer behavior due to internet technology has shortened product life cycles (Lebreton \& Tuma, 2006; Wu et al., 2006;
Xianhao \& Qizhi, 2007; Briano et al., 2010a). As a result, technology-based product becomes obsolete quickly (Beamon, 2008) and reaches its end-of-use (EOU), when consumer switches to product with newer technology even though the old product is still functioning. Technologybased product at its EOU usually still has a relatively high value, so it has the recovery or reuse potential. In addition to the economic benefit, the motivation for performing recovery process is reducing the waste disposed to the landfill by extending the life of product at its EOU, delaying product disposal or diverting its function. Thierry et al. (1995) identified several alternatives for recovery process, i.e. repairing, refurbishing, remanufacturing, cannibalization, recycling, and direct reuse. Remanufacturing is an option that gives the upgrade effect on the highest scale, which is expected to be a feasible option for recovering short life-cycle product at its EOU.

Most of remanufacturing literature considers durable or semi-durable products, such as heavy equipments, photocopiers, and automotive engines. However, life cycle of technology-based product is getting shorter and shorter, which poses a threat to sustainability in terms of excessive use of natural resources and energy, as well as faster landfil waste buildup. On the other hand, the huge availability of used products that still have value for use indicate potentials for remanufacturing. Therefore, we believe that remanufacturing of short life-cycle product could be a good approach for addressing this sustainability issue and for tapping the remaining values of the short-life cycle products at their EOU. However, we still need better understanding whether remanufacturing of short-life cycle products is economically feasible from the market point of view requires. In this study, we investigate the potential to remanufacture short life-cycle product. The study is divided into two major parts. The first is development of a decision model for remanufacturing shrt life cycle products, which is preseted in section 3. The second part is a survey of market potential for remanufactured mobile phone which is presented in section 4 . 


\section{REMANUFACTURING OF SHORT LIFE-CYCLE PRODUCT}

\subsection{Pros and Cons on short life-cycle product remanufacturing}

Remanufacturing is a process of transforming nonfunctional, removed or exchanged products into "like-new" condition (Lund \& Hauser, 2009; Gray \& Charter, 2008). Remanufacturing also results in reduction of energy and the use of natural materials, as well as reduction in the cost of production (Gray \& Charter, 2008). Additionally, Kaebernick et al. (2006) proposed that remanufacturing can improve the eco-efficiency and reduce environmental impact through the use of technology. Remanufacturing process involves collection of used products, inspection, disassembly, cleaning, reconditioning (includes repairs and upgrades), reassembly, and testing. One of the main problems in remanufacturing is retrieving sufficient amount of used products at the right quality. The amount and timing of product returns depends on the type of product. Factors such as products' useful life, the pace of technological innovation and the rate of components' failure also influence the rate of return from EOU products (Ostlin et al., 2009).

There are several findings that claim durability as one of the critical factors for successful remanufacturing. Lebreton \& Tuma (2006) claimed that by promoting aspects such as prestige, modernity or security, remanufactured items of those products tend to be discredited. Also, technology based commodities (such as mobile phone, computer) face short innovation cycles, which consequently make the previous generation psychologically and functionally obsolete. Gray \& Charter (2008) suggest that successful remanufacture requires that product technology is stable over more than one life cycle and unlikely to be successful when the evolution rate is high. The term evolution used here refers to technological change, legislation, and upgrade potential. In the mean time, Ostlin et al. (2009) and Ferguson \& Souza (2010) find that the rate of technological innovation and long useful life are the major influencing characteristics to the balance between product returns and demand for remanufactured products.

However, several studies find that life cycle of technology based products such as computers, mobile phones, and networking equipment is getting shorter due to rapid innovation in technology as well as rapid changes in customer preference (Lebreton \& Tuma, 2006; Wu et al., 2006; Xianhao \& Qizhi, 2007; Beamon, 2008; Guide et al., 2003; Helo, 2004, Briano et al., 2010b; Hsueh, 2011). When product life cycle is getting shorter, there would be more products discarded even though they are still in good conditions and well-functioning. This ultimately creates a problem on waste disposals. Green supply chain initiatives has been adopted as a respond to this problem, such as green purchasing, eco-design and reverse logistics (Eltayeb, 2009), and remanufacturing is one of several processes in conjuction with the reverse logistics. Even though some studies mentioned earlier implied that successful remanufacturing requires products to have long useful life and stable technology, there are several findings that support remanufacturing of short life cycle products. Steinhilper (1998) found the increasing volume of electronic products disposals that are not just look like new but also $80 \%$ of them are still working. This condition offers an ideal base for remanufacturing including modernization by upgrading or upcycling. He also suggested, if the whole electronic product can not be remanufactured, then remanufacturing of the components is also an important solution approach, which is also supported by Xing et al. (2007). Guide et al. (2003) show that remanufacturing of short life-cycle product is not only feasible, but can be profitable given well managed product acquisition. Remanufacturing of mobile phones has been studied by several authors in different countries and the findings shows that it has great potential in recapture value, recover assets, reduce energy and provide economic benefits (Franke et al., 2006; Tong, 2006; Chan \& Chan, 2008; Neto \& Bloemhof-Ruwaard, 2009; Rathore et al., 2011; Wang et al., 2011).

Remanufacturing also significantly reduces the amount of energy used in the product life cycle, even though the effectiveness of remanufacturing is very sensitive to the life span of the second life of the product. The period of the life cycle in which the product is returned to recovery, the quality of the product, the easiness to remanufacture and the consequent recovery costs can affect whether remanufacturing is more eco-efficient than manufacturing (Neto \& Bloemhof-Ruwaard, 2009; Neto et al., 2010; Neto \& Bloemhof-Ruwaard, 2012). Within the context of electronic and electrical equipments, Nnorom \& Osibanjo $(2008,2010)$ recommend careful use of products, repair, refurbishing and remanufacturing, as attempts to extend product life cycle. Again, the importance of remanufacturing of electronic products is stressed since remanufacturing can extend a product's life, improve the re-usability of components, reroute waste and energy, and at the same time create economic value. This finding is a corroboration of similar claim by Kerr \& Ryan (2001), Kaebernick et al. (2006) and Lee et al. (2010). Instead of considering the whole product, Kwak \& Kim (2013) recognize there is a significant challenge to product recovery for technological obsolescence of end-of-life product, and use the concept of part upgrades in remanufacturing. In Europe and the United States, the decisions to remanufacture electronic products are encouraged by government regulations such as WEEE (2003) and RoHs (2003), and as a form of responsibility for environmental conservation (Chung \& Wee, 2011). Considering the mounting wastes from electronic products nowadays, the potential of remanufacturing practices in reducing waste sent to the landfill, as well as in reducing production costs becomes clear. We believe that remanufacturing short life cycle product is rewarding economically as well as environmentally.

\subsection{Life-cycle implication}

Several studies have been done to investigate the life cycle impact on the reverse flow of the supply chain. Tibben-Lembke (2002) studies how reverse logistics is affected by changes in sales throughout the product life cycle. Product life cycle is divided into three levels, namely the product-class, products-format, and product-model. A new type of product belongs to the first category; a new form of existing product-class goes to second category, 
while a new model of existing product-form is placed in the last category. Georgiadis et al. (2006) studied how the product life cycle and optimal patterns of product-returns relate to the expansion decisions for collection and remanufacturing capacity, and influence the remanufacturing decisions. The relationship between residence time and length of product life cycle is also considered. As for the problem of balancing the supply and demand for remanufactured products, Ostlin et al. (2009) analyze the implications of the life cycle to the remanufacturing system, using three scenarios namely product remanufacturing, components remanufacturing and parts cannibalization. The period a product in the hands of consumers also influences the residual value of the product, which in turn affects the strategy of the reverse supply chain (Gobbi, 2011).

\subsection{Remanufacturing factors}

There are numerous studies in investigating the factors that influence decision to remanufacture as well as the factors for successful remanufacturing. We categorized the factors into four aspects, namely product characteristics, demand-related factors, process-related factors, and supplyrelated factors.

- Product characteristics of short life cycle products, consists of (1) innovation rate, as an extension to technology factor that was reported by Lund \& Hauser (2009), Ferguson \& Souza (2010), Souza (2009), and Lebreton (2007); (2) residence time as pointed out in Debo et al. (2005); (3) product residual value, according to a study by Gobbi (2008); and (4) qualitative obsolesce, as an extension to product characteristics, that was presented by Subramanian et al. (2013) and de Brito \& Dekker (2004).

- Demand-related factors, consists of (1) market size or existence of the demand, as reported in Ferguson \& Souza (2010), Souza (2009) and Vasudevan et al. (2012); (2) market channel, selling remanufactured products using the same channel as the new product, or differentiated, proposed by several authors i.e. Lund \& Hauser (2009), Ferguson \& Souza (2010), Souza (2009), Lebreton (2007), Debo et al. (2005), Thierry et al. (1995), Guide et al. (2003), and Geyer \& Jackson (2004); (3) pricing of new and remanufactured products, with demand as a function of, that was shown by Ovchinnikov (2011), Qiaolun et al. (2011), Qiaolun et al. (2008), Ferguson \& Toktay (2006), Ferguson \& Souza (2010), Souza (2009), and Guide et al. (2003); and (4) existence of green segment, proposed by Subramanian et al. (2013) and Atasu et al. (2008b).

- Supply-related factors can be described by: (1) acquisition price, and (2) source of return, whether it is limited and poses as a constraint, or unlimited These factors were studied by Lund \& Hauser (2009), Ferguson \& Souza (2010), Souza (2009), Subramanian et al. (2013), Vasudevan et al. (2012), and Ayres et al. (1997).

- The process-related factors consist of (1) remanufacturing technology availability, proposed by Lund \& Hauser (2009), Ferguson \& Souza (2010), and Ayres et al. (1997); (2) remanufacturing cost, as presented by Lund \& Hauser (2009), Ferguson \& Souza (2010), Souza (2009), Debo et al. (2005), Gobbi (2008), and Ayres et al. (1997);
(3) reverse flow structure readiness, that was reported in several studies i.e. Lund \& Hauser (2009), Lebreton (2007), Vasudevan et al. (2012), Ayres et al. (1997), Guide \& Wassenhove (2001), Zanoni et al. (2006), and Lashkari \& Zhang (2008).

\section{FRAMEWORK OF SHORT-LIFE CYCLE PRODUCT REMANUFACTURING}

From the literature review and our comprehension to the overall remanufacturing issues, we are able to develop a framework for remanufacturing of short life-cycle products. The framework is built started from identifying forward and reverse flow of the supply chain, and consider the possible alternatives when dealing with short life-cycle products. In terms of product life-cycle level, we only consider productmodel, since new model is lauched in a very short period after launching the current model of the technology-based commodity. But for product form and product class, the length of life-cycle is quite long.

\subsection{Short life-cycle remanufacturing flow}

New product model introductions are usually very effective for early adopters and high end customers, where added features are not too significant to change the product form but mostly for improving convenience or fashionable design, as well as for increasing the level of emotional attachment between product and user (Tibben-Lembke, 2002). Since product-class and product-form have been introduced earlier, remanufacturing of product-model could be implemented with less complication. Acquisition of used product, or collection scheme, can be very challenging because there is high uncertainty in the quantity and quality of the returns, as well as reverse supply chain network problems. However, collection scheme for product-model is often similar to the one for existing product-class or product-form; therefore the readiness is usually higher in terms of network availability which could reduce uncertainty in returns quantity. Also, some firms consider that effective return management can impact on competitive advantage (Hsiao, 2010; Vidovic et al., 2011). Quality problems usually are not too significant since customers have learned from the previous levels about the quality of remanufactured product compared to new product. Since maturity phase is typically very short, the design of supply chain flow is important.

There are many reasons behind product returns as explored by de Brito \& Dekker (2004), and categorized into manufacturing returns, distribution returns and customer returns. Faulty, left-over and by-product within manufacturing returns are internal ones which usually have been accounted in the manufacturing processes. Most of the distribution returns are suitable for remanufacturing because they retain highest added value; as they are typically business-to-business (B2B) commercial returns such as unsold or damaged deliveries, or they could be the results of stock adjustments and product recalls. Short life-cycle products within this distribution time frame would still have high innovation value, and would be good inputs for repair and remanufacturing. As for customer returns, there are only 
several types of returns that would be suitable for remanufacturing; those are business-to-consumer (B2C) commercial returns, warranty and service returns. End-ofuse customer returns are not all remanufacturable, since sorting and inspection are required beforehand. However, some of the returns may not be good for remanufacturing, such as end-of-life customer returns. We propose a short life-cycle product remanufacturing flow as depicted in Figure 1.

\subsection{Recovery Options}

Product returns may occur for several reasons over the product life-cycle, as pointed out by Flapper et al. (2005), Guide \& Wassenhove (2009), and Cuc \& M Vidovic (2011). Dominant pairings between type of returns and recovery options are provided by Guide \& Wassenhove (2009). Remanufacturing is not limited to product remanufacturing but also include component remanufacturing, as suggested by Ostlin et al. (2009), Xing et al. (2007), and Steinhilper (1998). We extend Guide \& Wassenhove's pairings to differentiate product and component remanufacturing and to include the type of market for recovered product. Since B2B and $\mathrm{B} 2 \mathrm{C}$ commercial returns are obtained within a short period of time, they are in prime conditions for short lifecycle product remanufacturing; and given the expedited process, the recovered products can be sold in the original product's primary market. End-of-use (EOU) customer returns are usually collected later than B2B and B2C commercial returns, which in turn undergo partial obsolescence risk. Even though this type of returns are still suitable for remanufacturing, but the recovered product might not be able to get the same perceived quality from customers, which consequently should be sold in product's secondary market. However, if the manufacturer is interested in component remanufacturing, the recovered parts can be marketed in the component primary market, since the life cycle of the components are typically longer than the product itself. As for end-of-life (EOL) customer returns, considering the short life-cycle of the product, the effect of obsolescence has been significant enough to debilitate effective remanufacturing. Therefore, it is better to harvest some components to be remanufactured and then sold to secondary market, or just extract the valuable materials in the recycling process. A pairing between type of returns and recovery options is given to decide the type of market for recovered items, which is shown in Figure 2.

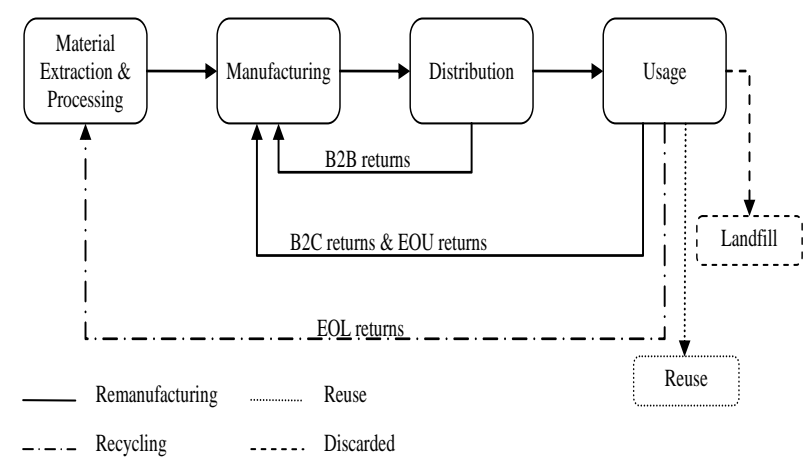

Figure 1. Short life-cycle remanufacturing flow

\begin{tabular}{|c|c|c|c|}
\hline Recycle & & & $\begin{array}{l}\text { material } \\
\text { primary } \\
\text { market }\end{array}$ \\
\hline $\begin{array}{l}\text { Component } \\
\text { remanufac- } \\
\text { turing }\end{array}$ & & $\begin{array}{c}\text { component } \\
\text { primary } \\
\text { market }\end{array}$ & $\begin{array}{c}\text { component } \\
\text { secondary } \\
\text { market }\end{array}$ \\
\hline $\begin{array}{l}\text { Product } \\
\text { remanufac- } \\
\text { turing }\end{array}$ & $\begin{array}{l}\text { product } \\
\text { primary } \\
\text { market }\end{array}$ & $\begin{array}{c}\text { product } \\
\text { secondary } \\
\text { market }\end{array}$ & \\
\hline Rerevery & $\begin{array}{c}\text { B2B \& } \\
\text { Consumer } \\
\text { returns }\end{array}$ & EOU & EOL \\
\hline
\end{tabular}

Figure 2. Recovery options and type of returns

\subsection{Framework}

Before engaging in remanufacturing of short life-cycle products, there are several considerations need to be taken into account. The first step is identifying the remanufacturing flow and recovery options. When remanufacturing is considered as an appropriate option, whether product or component remanufacturing, then it is necessary to design the remanufacturing system based on the aspects described in section 2.3. In this way, a comprehensive analysis is performed to ensure successful remanufacturing. The framework is presented in Figure 3.

\section{MARKET SURVEY FOR REMANUFACTURED MOBILE PHONES}

In order to understand the market potential of remanufactured short life cycle products, we conducted a study that would provide a descriptive statistics of predetermined attributes. The framework presented in Figure 3 shows remanufacturing aspects that need to be considered when engaging in remanufacturing of short lifecycle product. Guide \& Wassenhove (2009) propose that among three key activities within reverse supply chain, namely frond-end (product returns management), engine (remanufacturing operations issues), and back-end (market development for remanufactured product), remarketing is the most recent aspect in the evolution of closed-loop supply chain, focusing on profitable value recovery of product returns. We use the items under remarketing aspects, which are market size, pricing, and green segment to design the market survey. Market channel is not investigated in this study because retailer's physical stores are the most reliable data source for all groups of participants.

The objectives of the survey are obtaining insights and preliminary information about

1. Existence of demand - which gives insight into the potential market size,

2. Customers' willingness to pay (WTP) - which gives insight into the pricing strategy,

3. Existence of green segment.

Short life-cycle product considered here is a product with a high innovation rate and with characteristic that EOU occurs before product's end-of-life (EOL), specifically mobile phones. There are two product types considered, namely (1) reuse product, a used product that is sold without reconditioning (as it is) through stores or directly among customers, and (2) remanufactured product, a used product that is sold after reconditioned to "as good as new" state. 


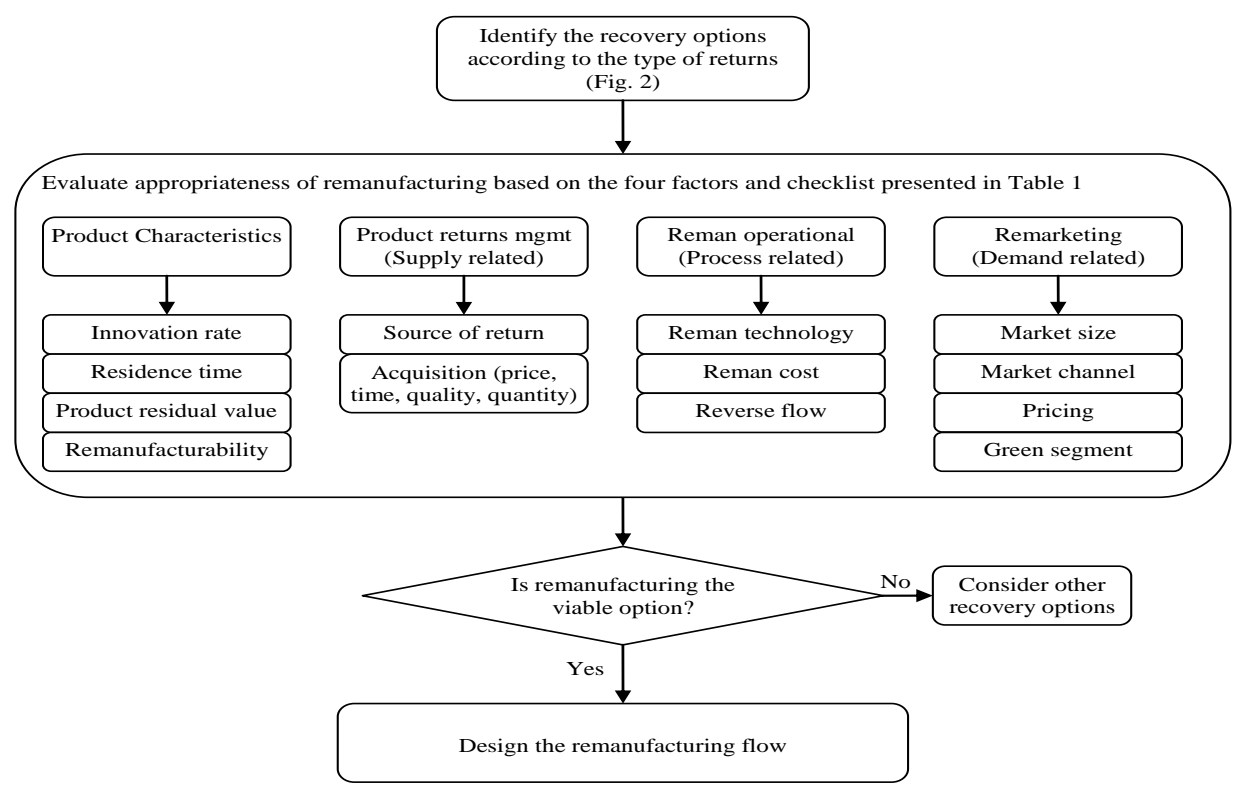

Figure 3. Framework for remanufacturing of short life-cycle product

\subsection{Research Design}

This study uses quantitative research design to obtain the frequency and proportion of the attributes mentioned in the survey objectives. It is an exploratory research, which is intended to expand understanding and provide insights into the market potential. We choose survey method for gathering data because it provides several advantages. The nature of our study is obtaining insights and preliminary information which would not require a form of interview; it would be well represented by a questionnaire which in turns provides better economy of design. Also, the convenient data gathering allows sufficient amount of participants which support higher representative for the attributes being studied. Since we do not focus on the behavior of attributes over time, we use cross sectional survey that was conducted in October 2012. This survey is administered to the participants through questionnaire-based interview and selfadministered questionnaires. Considering that some of our targeted participants have limited academic background, we provide them with interviewers who will ask and explain the questions as well as the choices of responses; which is important to obtain higher precision data. However, for well-educated participants, the questionnaires are executed without interviewers, which would provide higher privacy on the participants' side and lower execution cost on researcher's side.

Table 1. Checksheet for assessing remanufacturability of short life cycle products

\begin{tabular}{|c|c|c|c|}
\hline Factors & Items & In support of remanufacturing & Against remanufacturing \\
\hline \multirow{4}{*}{ Product } & Innovation rate & Stable & Unstable \\
\hline & Residence time & Short & Long \\
\hline & $\begin{array}{l}\text { Product } \\
\text { residual value }\end{array}$ & High & Low \\
\hline & $\begin{array}{l}\text { Remanufactura } \\
\text { bility }\end{array}$ & High & Low \\
\hline \multirow{3}{*}{ Process } & $\begin{array}{l}\text { Remanufacturi } \\
\text { ng technology }\end{array}$ & Available & Not available \\
\hline & $\begin{array}{l}\text { Remanufacturi } \\
\text { ng cost }\end{array}$ & Within acceptable range & Beyond acceptable range \\
\hline & Reverse flow & Available or easy to develop & Not available and uneasy to develop \\
\hline \multirow[t]{2}{*}{ Supply } & $\begin{array}{l}\text { Source of } \\
\text { return }\end{array}$ & Sufficiently available & Not sufficiently available \\
\hline & Acquisition & Easy to obtain & Uneasy to obtain \\
\hline \multirow{4}{*}{ Demand } & Market size & Large market size & Small market size \\
\hline & Market channel & Available or easy to develop & Not available and uneasy to develop \\
\hline & Pricing & Price is attractive and feasible & Price is neither attractive nor feasible \\
\hline & Green segment & $\begin{array}{l}\text { There are customers that would buy } \\
\text { remanufacturing products for environmental } \\
\text { reasons }\end{array}$ & $\begin{array}{l}\text { Customers would only consider economic and/or } \\
\text { psycho-sociological factors }\end{array}$ \\
\hline
\end{tabular}



Operations and Supply Chain Management 7(1) pp. 13-22 @ 2014

The population in our study is mobile-phone users in Surabaya Indonesia. The size of the population is approximated 2.4 million, based on data from Central Agency on Statistics, Indonesia. We apply stratification in the single stage sampling design to understand each stratum's opinion. There are 2 major groups of samples, which are sellers and buyers, which is shown in Figure 4. We believe that sellers and buyers could have different perspectives that form their opinions on remanufactured products' market demand, WTP, and preference over reused products. The buyers are further divided into 3 sub-groups namely high-end groups (HE) with high income and high IT awareness; low-end group (LE) with low income and typically low IT awareness; and student group (SG) with typically low income but high IT awareness. It is our intention to identify the most potential group for marketing remanufactured products. Numbers of samples are 30 for sellers and 55 for each sub-group of buyer. The participants are selected randomly based on their arrival to the cell phone centers in Surabaya, which are Plaza Marina, Hitech Mall, and World Trace Center Surabaya.

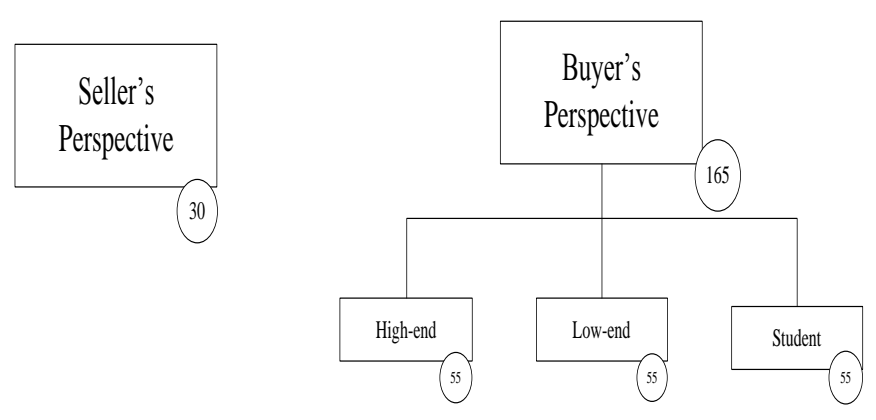

Figure 4. Sampling design
Data were collected by using questionnaires that consist of 5 items for seller group and each of the buyer group. The questions are in the form of multiple choices using nominal or categorical scale (showing preference and choices) and intervals (identifying WTP and price). The instrument design starts with the investigative questions that later would lead to relevant items on survey. In the preliminary analysis plan, we determine the scale type, communication approach, and structure of the questions. Scale selection is rooted on the type of the study. Since it is an exploratory descriptive study, which searches for opinion and frequency characteristics; we use nominal and interval scale. As for the communication approach, we administer both questionnairebased interview and self-administered questionnaire. Highend and student participants are considered to be more independent in filling out the questionnaire and prefer higher privacy, which is suitable for the latter approach. The qustionnaire consists of administrative and classification questions which serve as identification of the participants as well as their grouping; and target questions which address the investigative questions. The questionnaire is then tested to 5 individuals to check whether the questions are clear, and whether we have chosen the suitable scale, structures and response strategy. This test is followed by improvement of questions, format and scales, before ready to be lauched, as shown in Figure 5.

We develop survey questions based on the survey objectives, but they are limited to exploration purpose and not for testing hypothesis. Therefore, most of the questions are categorical and the responses would be processed to find proportion or frequency of opinions. The relation between variable, research question or survey objectives, and items on survey is given in Table 2 .

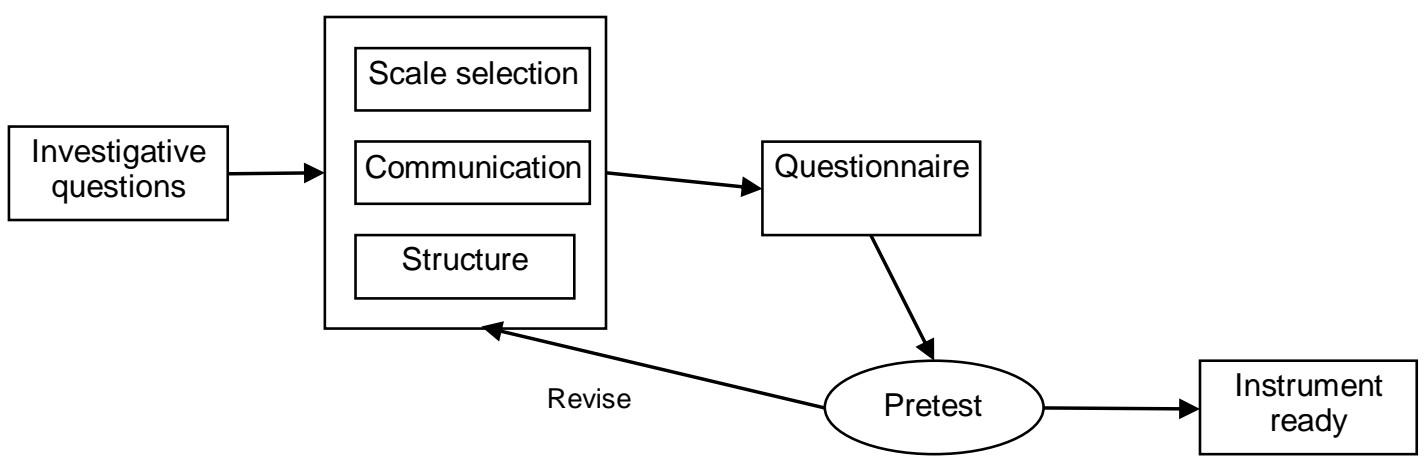

Figure 5. Instrument design

\subsection{Survey results and analysis}

The results show that demand of remanufactured mobile phone does exist, even though it is relatively low. From the seller's point of view, most customers would prefer to buy used mobile phones rather than remanufactured ones. About $68 \%$ participants believe that given remanufactured or used-phones options, customers would choose used phones at lower price even though there is no warranty. Seller also believes that low-end customer has highest preference to buy remanufactured products compared to the other two sub-groups. When consumer decides to buy remanufactured phone, $89 \%$ participants believe that warranty is the most important factor. Futher observations show that $68 \%$ participants consider the appropriate price of a remanufactured phone is between $40 \%-60 \%$ of the price of the respective new product. The six diagrams in Figure 6 show the survey results from seller's point of view. 
Table 2. Relation between variable, survey objectives, and items on survey

\begin{tabular}{|c|c|c|c|}
\hline Survey Objective & Variable name & Item on Survey - Seller & Item on Survey - Buyer \\
\hline \multirow[t]{2}{*}{$\begin{array}{l}\text { Does the demand } \\
\text { for remanufactured } \\
\text { short life-cycle } \\
\text { product exist? }\end{array}$} & $\begin{array}{l}\text { Proportion of customer who } \\
\text { would buy reman product }\end{array}$ & $\begin{array}{l}\text { Question A1: customer preference to buy reman } \\
\text { over reuse; } \\
\text { Question A2: customer preference to buy reman } \\
\text { over new and reuse }\end{array}$ & $\begin{array}{l}\text { Question B1: customer preference to buy } \\
\text { reman product over new and reuse }\end{array}$ \\
\hline & $\begin{array}{l}\text { Sub-group that prefer reman } \\
\text { product }\end{array}$ & $\begin{array}{l}\text { Question A3: group of customer that would buy } \\
\text { reman product }\end{array}$ & $\begin{array}{l}\text { Question B2: group of customer that would } \\
\text { buy reman product }\end{array}$ \\
\hline \multirow{2}{*}{$\begin{array}{l}\text { How much is the } \\
\text { customer's WTP for } \\
\text { remanufactured } \\
\text { short life-cycle } \\
\text { product? }\end{array}$} & Customer's WTP & $\begin{array}{l}\text { Question A4: percentage of customer's WTP } \\
\text { compared to new one }\end{array}$ & $\begin{array}{l}\text { Question B3: percentage of customer's WTP } \\
\text { compared to new one }\end{array}$ \\
\hline & $\begin{array}{l}\text { Factor the influence } \\
\text { customer's WTP }\end{array}$ & $\begin{array}{l}\text { Question A5: Among residence time, warranty, } \\
\text { and environment awareness; which one would } \\
\text { influence customer's WTP the most? }\end{array}$ & $\begin{array}{l}\text { Question B4: Among reman by OEM, } \\
\text { residence time, warranty, and environment } \\
\text { awareness; which one would influence } \\
\text { customer's WTP the most? }\end{array}$ \\
\hline $\begin{array}{l}\text { Does green } \\
\text { segment exist? }\end{array}$ & Existence of green segment & -- & $\begin{array}{l}\text { Question B5: Does environment factor } \\
\text { influence the decision to buy reman product? }\end{array}$ \\
\hline
\end{tabular}

Customers willingness to pay is different among highend, low-end and students. The cumulative customers' WTPs are depicted in Figure $7 \mathrm{a}$. When the remanufactured item's price is less than $40 \%$ of new product, $95 \%$ of lowend cstomers and $91 \%$ of students will buy it, but only $60 \%$ high-end customers are willing to buy. Low-end customers are the sub-group that has least resistance towards buying remanufactured product, as shown in Figure $7 \mathrm{~b}$. When given the option to buy new and used products besides remanufactured ones, $81 \%$ high-end customers and 93\% students choose to buy new phones; only $15 \%$ and $5 \%$ favor in remanufactured phones, respectively. On the other hand, $41 \%$ low-end customers prefer to buy remanufactured phones with warranty, $37 \%$ choose new products, and $22 \%$ favors used phones. Customer's responses can be seen in Figure 7c. As for the factor that effect the price of remanufactured product, the highest choice of high-end and student customers is warranty and then "remanufactured by OEM", but for low-end customers the highest tally is environment awareness followed by warranty, as shown in Figure 7d. The existence of green segment can be identified from customer response depicted in Figure 7e, where $65 \%$ of low-end customer.

The above results indicated that remanufactured product is not attractive for high-end customers. Also, students' opinion does not firmly support remanufacturing when assessed from several aspects above. Hence, remanufactured product sales should target low-end customers. The existence of green segment could be a potential market as well, which should be responded with suitable advertisement. Customer's WTP is relatively low, which could be influenced by the vague difference in quality perception between remanufactured and used products. This is understandable because participants have not received enough information and do not have sufficient experience with remanufactured product. Since warranty is an important factor of attractiveness, it should be provided for remanufactured product in contrast to used product.

\section{CONCLUSION}

The presented discussion has shown that despite the common idea that remanufacturing requires product with long life-cycle and stable technology, we are able to show findings that support remanufacturing of short life-cycle product. The literature review results in the findings about life cycle implication as well as factors that influence the decision to remanufacture and to perform successful remanufacturing. A framework for remanufacturing of short life-cycle product has been presented to understand the supply chain flow, relations between type of returns and recovery options as well as type of market, and remanufacturing aspects that influence the decision to remanufacturing. We also conducted a survey, which is intended to provide insights on market potential of remanufactured mobile phone. The survey results support the remanufacturing of mobile phone based on remarketing factors. Based on the checklist in Table 1, we find that there is sufficient market size within low-end customers. Lower price is also an attractive factor for this type of customers, where $95 \%$ of participants willing to buy remanufactured mobile phone when it is priced at $40 \%$ of the new product. We also identify the existence of green segment where $42 \%$, $65 \%$, and $47 \%$ of customers from high-end, low-end, and student sub-group respectively consider buying remanufactured products over new ones driven by their concerns for the environment. However, to obtain a more general conclusion, the other factors should also be investigated further i.e. product characteristics, product return management, and remanufacturing operations. Other related research may include empirical as well as modeling approaches. The empirical reseach with stronger population base is necessary to gain a more statistically robust survey results. On the other hand, modeling works related to various aspects would give insights on such factors as prices, supply variability of used products and demand uncertainty . 


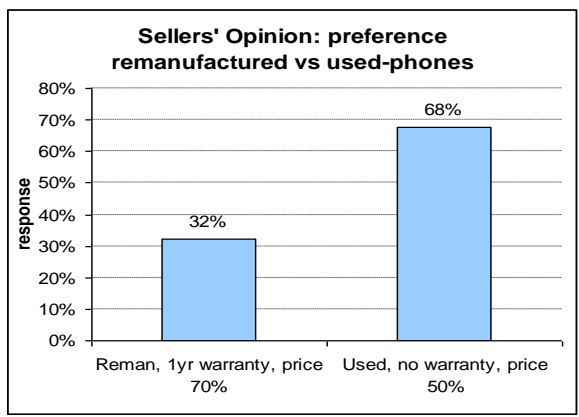

(a)

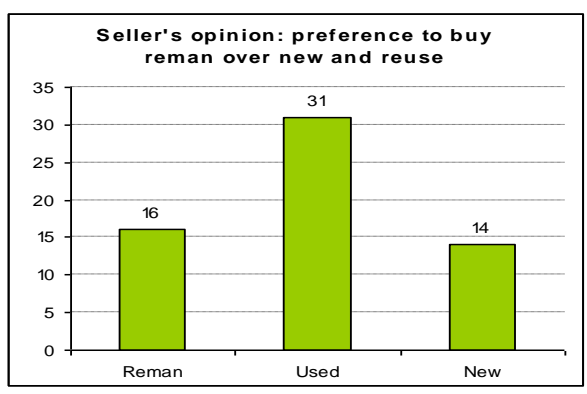

(b)

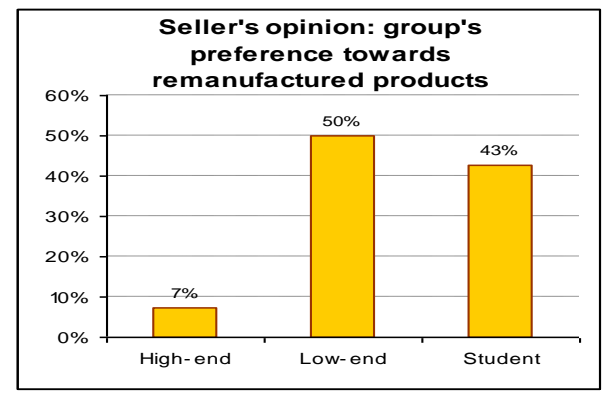

(c)

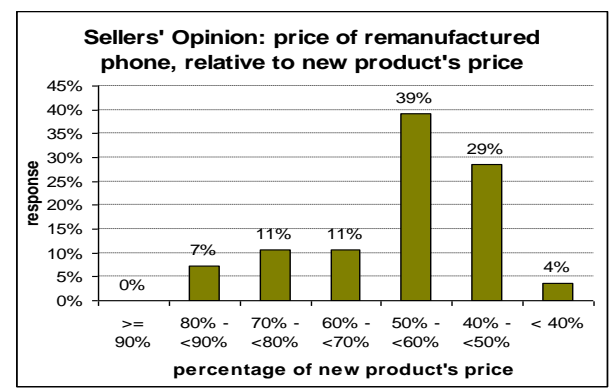

(d)

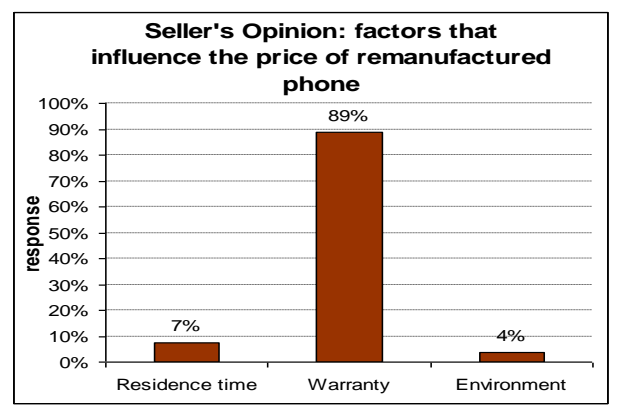

(e)

Figure 6. Survey results - seller's opinion on remanufactured products

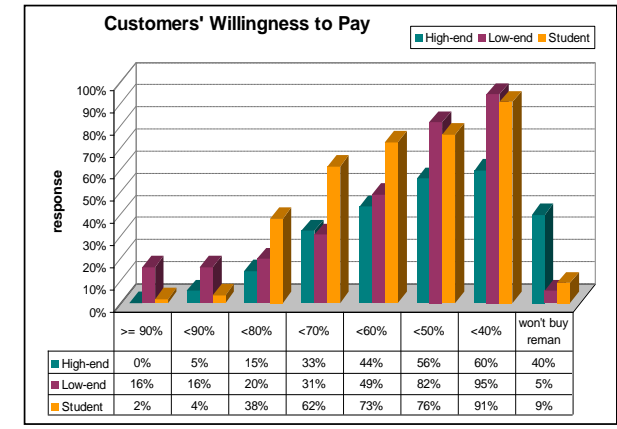

(a)

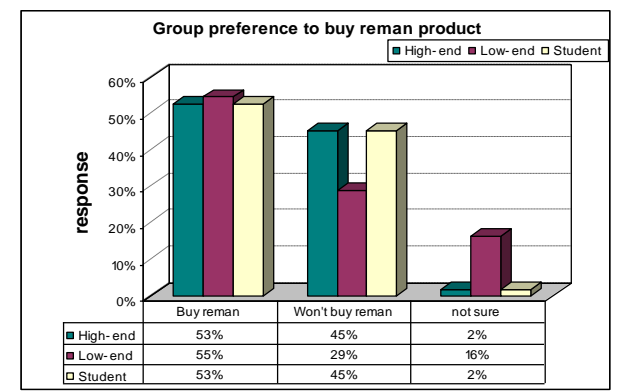

(b)

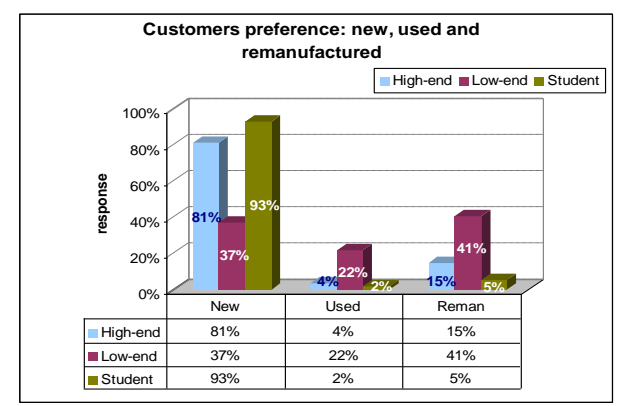

(c)

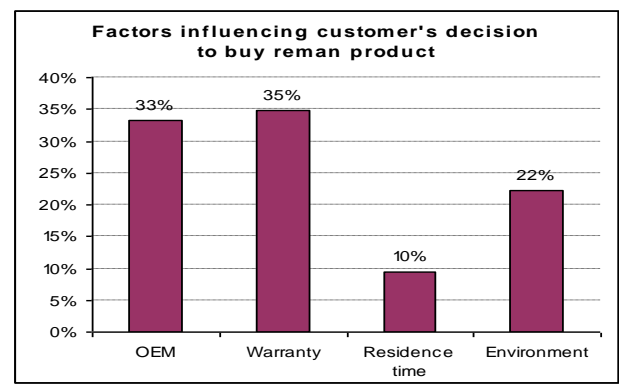

(d)

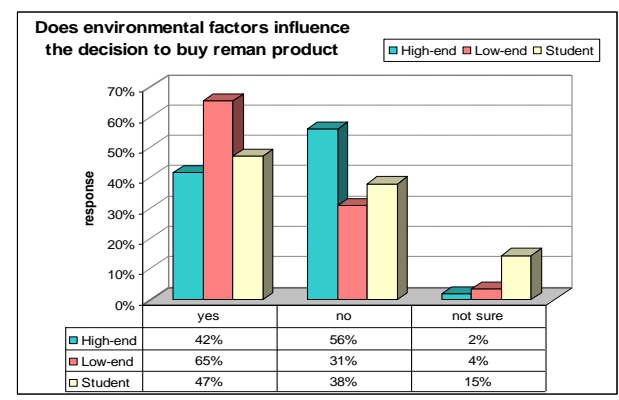

(e)

Figure 7. Customers' responses to WTP and preference 


\section{REFERENCES}

Atasu, A., Sarvary, M. \& Wassenhove, L.N.V., (2008). Remanufacturing as a Marketing Strategy. Management Science, 54(10), pp.1731-1746.

Ayres, R.U., Ferrer, G. \& Van Leynseele, T., (1997). Ecoefficiency, Asset Recovery and Remanufacturing. European Management Journal, 15(5), pp.557-574.

Beamon, B.M., (2008). Sustainability and the Future of Supply Chain Management. Operations and Supply Chain Management, 1(1), pp.4-18.

Briano, E., Caballini, C., Giribone, P. \& Revetria, R., (2010a), Resiliency and Vulnerability in Short Life Cycle Products' Supply Chains: a System Dynamics Model. Wseas Transactions on Systems, 9(4), pp.327-337.

Briano, E., Caballini, C., Giribone, P. \& Revetria, R., (2010b). Using a System Dynamics Approach for Designing and Simulation of Short Life-Cycle Products Supply Chain. In $S$ Lagakos et al., eds. CEA'10 Proceedings of the 4th WSEAS international conference on Computer engineering and applications. World Scientific and Engineering Academy and Society (WSEAS) Stevens Point, Wisconsin, USA (C)2009, pp. 143-149.

de Brito, M.P. \& Dekker, R., (2004). A Framework for Reverse Logistics. In L. N. Dekker, R., Fleischmann, M., Inderfurth, K., Van Wassenhove, ed. Reverse Logistics: Quantitative Models for Closed-Loop Supply Chains. Springer-Verlag, Heidelberg, pp. 3-27.

Chan, F.T.S. \& Chan, H.K., (2008). A Survey on Reverse Logistics System of Mobile Phone Industry in Hong Kong. Management Decision, 46(5), pp.702-708.

Chung, C.-J. \& Wee, H.-M., (2011). Short Life-cycle Deteriorating Product Remanufacturing in a Green Supply Chain Inventory Control System. International Journal of Production Economics, 129(1), pp.195-203.

Cuc, S. \& Vidovic, M, (2011). Environmental Sustainability through Clothing Recycling. Operations and Supply Chain Management, 4(2), pp.108-115.

Debo, L.G., Toktay, L.B. \& Wassenhove, L.N.V., (2005). Market Segmentation and Product Technology Selection for Remanufacturable Products. Management Science, 51(8), pp.1193-1205.

Eltayeb, T.K., (2009). Going Green through Green Supply Chain Initiatives towards Environmental Sustainability. Operations and Supply Chain Management, 2(2), pp.93-110.

Ferguson, M.E. \& Souza, G.C., (2010). Closed-loop supply Chains - New Developments to Improve the Sustainability of Business Practices, CRC Press.

Ferguson, M.E. \& Toktay, L.B., 2006. The Effect of Competition on Recovery Strategies. Production and Operations Management, 15(3), pp.351-368.

Flapper, S.D.P., Nunen, J.A.E.E. van \& Wassenhove, L.N.V., (2005). Managing Closed-loop Supply Chain, Springer.

Franke, C., Basdere, B., Ciupek, M., \& Seliger, S. (2006). Remanufacturing of Mobile Phones - Capacity, Program and Facility Adaptation Planning. Omega, 34, pp.562 - 570.

Georgiadis, P., Vlachos, D. \& Tagaras, G., (2006). The Impact of Product Lifecycle on Capacity Planning of Closed-Loop Supply Chains with Remanufacturing. Production and Operations Management, 15(4), pp.514-527.

Geyer, R. \& Jackson, T., (2004). Supply Loops and Their Constraints: The Industrial Ecology of Recycling and Reuse. California Management Review, 46(2), pp.55-73.

Gobbi, C., (2011). Designing the Reverse Supply Chain: The Impact of the Product Residual Value. International Journal of Physical Distribution \& Logistics Management, 41(8), pp.768-796.

Gobbi, C., (2008). The Reverse Supply Chain: Configuration, Integration and Profitability. Technical University of Denmark.
Gray, C. \& Charter, M., (2008). Remanufacturing and Product Design. International Journal of Product Development, 6(34), pp.375-392.

Guide, V.D.R.J. \& Wassenhove, L.N.V., (2001). Managing Product Returns for Remanufacturing. Production and Operations Management, 10(2), pp.142-155.

Guide, V.D.R.J. \& Wassenhove, L.N.V., (2009). The Evolution of Closed-Loop Supply Chain Research. Operations Research, 57(1), pp.10-18.

Guide, V.D.R.J., Jayaraman, V. \& Linton, J.D., (2003). Building Contingency Planning for Closed-loop Supply Chains with Product Recovery. Journal of Operations Management, 21, pp.259-279.

Guide, V.D.R.J., Teunter, R.H. \& Wassenhove, L.N.V., (2003). Matching Demand and Supply to Maximize Profits from Remanufacturing. Manufacturing \& Service Operations Management, 5(4), pp.303-316.

Helo, P., (2004). Managing Agility and Productivity in the Electronics Industry. Industrial Management \& Data Systems, 104(7), pp.567-577.

Hsiao, J. M. M., (2010). Building Competitive Advantage through Innovative Reverse Logistics Capabilities. Operations and Supply Chain Management, 3(2), pp.70-82.

Hsueh, C. F. (2011). An Inventory Control Model with Consideration of Remanufacturing and Product Life Cycle. International Journal of Production Economics, 133(2), pp.645-652.

Kaebernick, H., Manmek, S. \& Anityasari, M., (2006). Future Global Manufacturing. Are there Environmental Limits and Solutions? In The International Manufacturing Leaders Forum (IMLF), Taiwan. pp. 1-11.

Kerr, W. \& Ryan, C., (2001). Eco-efficiency Gains from Remanufacturing - A Case Study of Photocopier Remanufacturing at Fuji Xerox Australia. Journal of Cleaner Production, 9, pp.75-81.

Kwak, M. \& Kim, H., (2013). Market Positioning of Remanufactured Products with Optimal Planning for Part Upgrades. Journal of Mechanical Design, 135(January), pp.1-10.

Lashkari, R.S. \& Zhang, H.H., (2008). Modeling and Analysis of a Reverse Supply Chain Network for Lead-Acid Battery Manufacturing. Operations and Supply Chain Management, 1(1), pp.43-56.

Lebreton, B., (2007). Strategic Closed-Loop Supply Chain Management. In Lecture Notes in Economics and Mathematical Systems 586. Springer Berlin Heidelberg, pp. $1-158$.

Lebreton, B. \& Tuma, A., (2006). A quantitative approach to assessing the profitability of car and truck tire remanufacturing. International Journal of Production Economics, 104, pp.639-652.

Lee, H.B., Cho, N.W. \& Hong, Y.S., (2010). A Hierarchical Endof-Life Decision Model for Determining the Economic Levels of Remanufacturing and Disassembly under Environmental Regulations. Journal of Cleaner Production, 18(13), pp.1276-1283.

Lund, R.T. \& Hauser, W.M., (2009). Remanufacturing - An American Perspective,

Neto, J.Q.F. \& Bloemhof-Ruwaard, J.M., (2012). An Analysis of the Eco-Efficiency of Personal Computers and Mobile Phones. Production and Operations Management, 21(1), pp.101-114.

Neto, J.Q.F. \& Bloemhof-Ruwaard, J.M., (2009). The Environmental Gains of Remanufacturing: Evidence from the Computer and Mobile Industry, ERIM Report Series Management, ERS-2009-024-LIS. Academic Repository at Erasmus University.

Quariguasi Frota Neto, J., Walther, G., Bloemhof, J., Van Nunen, J. A. E. E., \& Spengler, T. (2010). From closed-loop to 
sustainable supply chains: the WEEE case. International Journal of Production Research, 48(15), 4463-4481.

Nnorom, I.C. \& Osibanjo, O., (2010). Overview of Prospects in Adopting Remanufacturing of End-of-Life Electronic Products in the Developing Countries. International Journal of Innovation, Management and Technology, 1(3), pp.328338.

Nnorom, I.C. \& Osibanjo, O., (2008). Overview of Electronic Waste (e-waste) Management Practices and Legislations, and Their Poor Applications in the Developing Countries. Resources, Conservation and Recycling, 52(6), pp.843-858.

Ostlin, J., Sundin, E. \& Bjorkman, M., (2009). Product Life-cycle Implications for Remanufacturing Strategies. Journal of Cleaner Production, 17(11), pp.999-1009.

Ovchinnikov, A., (2011). Revenue and Cost Management for Remanufactured Products. Production and Operations Management, 20(6), pp.824-840.

Qiaolun, G., Jianhua, J. \& Tiegang, G., (2011). Pricing Decisions for Reverse Supply Chains. Kybernetes, 40(5/6), pp.831841.

Qiaolun, G., Jianhua, J. \& Tiegang, G., (2008). Pricing Management for a Closed-loop Supply Chain. Journal of Revenue and Pricing Management, 7(1), pp.45-60.

Rathore, P., Kota, S. \& Chakrabarti, A., (2011). Sustainability through Remanufacturing in India: A Case Study on Mobile Handsets. Journal of Cleaner Production, 19, pp.1709-1722.

Souza, G.C., (2009). Remanufacturing in Closed-loop Supply Chains. Production and Inventory Management Journal, 45(1), pp.56-66.

Steinhilper, R., (1998). Remanufacturing - The Ultimate Form of Recycling, Fraunhofer IRB Verlag.

Subramanian, R., Ferguson, M.E. \& Toktay, L.B., (2013). Remanufacturing and the Component Commonality Decision. Production and Operations Management 22(1), pp.36-53.
Thierry, M., Salomon, M., Van Nunen, J., \& Van Wassenhove, L. (1995). Strategic issues in product recovery management. California Management Review, 37(2), pp.114-135.

Tibben-Lembke, R.S., (2002). Life After Death: Reverse Logistics and the Product Life Cycle. International Journal of Physical Distribution \& Logistics Management, 32(3), pp.223-244.

Tong, B., (2006). Research on the Cell Phone Remanufacturing and Reselling.

Vasudevan, H., Kalamkar, V. \& Terkar, R., (2012). Remanufacturing for Sustainable Development: Key Challenges, Elements, and Benefits. International Journal of Innovation, Management and Technology, 3(1), pp.84-89.

Vidovic, M., Ratkovic, B., Bjelic, N., and Popovic, D., (2011). Optimization of Recyclables Collection Processes. Operations and Supply Chain Management, 4(2), pp.90-98.

Wang, J., Zhao, J. \& Wang, X., (2011). Optimum Policy in Hybrid Manufacturing / Remanufacturing System. Computers \& Industrial Engineering, 60, pp.411-419.

Wu, S.D., Aytac, B., Berger, R., and Armbruster, C. (2006). Managing Short-Lifecycle Technology Products for Agere Systems. Interfaces 36(3), pp.234-247.

Xianhao, X. \& Qizhi, S., (2007). Forecasting for Product with Short Life Cycle Based on Improved Bass Model. Industrial Engineering and Management, 12(5).

Xing, K., Belusko, M., Luong, L., \& Abhary, K. (2007). An Evaluation Model of Product Upgradeability for Remanufacture. The International Journal of Advanced Manufacturing Technology, 35(1-2), pp.1-14.

Zanoni, S., Ferretti, I. \& Tang, O., (2006). Cost performance and bullwhip effect in a hybrid manufacturing and remanufacturing system with different control policies. International Journal of Production Research, 44(18-19), pp.3847-3862.

Shu San Gan is a Lecturer at Petra Christian University, Mechanical Engineering Department. She received her bachelor Diploma in Mathematics from Sepuluh Nopember Institute of Technology (ITS), Surabaya, Indonesia. She earned her Master's degree in Applied Mathematics from Michigan State University, East Lansing, USA. She is currenty a PhD Candidate at Industrial Engineering Department, Sepuluh Nopember Institute of Technology (ITS), Surabaya, Indonesia. Her research area is optimization in supply chain management, with special attention to closed-loop supply chain.

I Nyoman Pujawan is Professor of Supply Chain Engineering at the Department of Industrial Engineering, Sepuluh Nopember Institute of Technology (ITS), Surabaya, Indonesia. He received a bachelor degree in Industrial Engineering from ITS, M.Eng in Industrial Engineering from Asian Institute of Technology (AIT), Thailand, and PhD in Management Science from Lancaster University, UK. He has published articles in various international journals including the European Journal of Operational Research, International Journal of Production Research, International Journal of Production Economics, Production Planning and Control, Business Process Management Journal, International Journal of Industrial and Systems Engineering, among others.

Suparno is a Professor of Operations Management at the Department of Industrial Engineering, Sepuluh Nopember Institute of Technology (ITS), Surabaya, Indonesia. He received his bachelor degree in Industrial Engineering from Bandung Institute of Technology (ITB), Bandung, Indonesia, Master's degree in Industrial Engineering from University of Wisconsin, Madison, USA, and Ph.D in Engineering Management from University of Strathclyde, UK. He was the former Head of the Industrial Engineering Department, ITS and the former Director of the Postgraduate Study ITS. His research interests include, among other things, optimization of manufacturing systems and supply chain management. 